\title{
GIS BASED WATER SUITABILITY CLASSIFICATION FOR SHEEP - A CASE STUDY OF SAVADKOOH WATERSHED, MAZANDARAN, IRAN
}

\author{
ALISHAH ARATBONI, F. ${ }^{1}$ - ARZANI, H. ${ }^{2 *}-$ JAVADI, S. A. $^{1}-$ FARAHPOUR, M. ${ }^{3}$ \\ ${ }^{I}$ Department of Range Management, Science and Research Branch, Islamic Azad University \\ Tehran, Iran \\ ${ }^{2}$ Faculty of Natural Resources, University of Tehran, Karaj, Iran \\ ${ }^{3}$ Research Institute of Forests and Rangelands, Tehran, Iran \\ *Corresponding author \\ e-mail: harzani@ut.ac.ir; phone: 09123634046 \\ (Received $11^{\text {th }}$ Oct 2016; accepted $1^{\text {st }}$ Mar 2017)
}

\begin{abstract}
Water resources are of utmost importance for proper grazing management and optimal use of rangelands. In the present study, suitability of lands from the perspective of water resources is modeled regarding sheep as the grazing livestock. FAO (1991) method was used for the model. The study area is located at Savadkooh, Mazandaran province of Iran. The model comprised three submodels; water quality, water quantity and the distance of water resources to grazing area. According to the climatic conditions and number of permanent water resources, there was no shortage in water quantity. Results of water analysis also revealed no restricted elements for sheeps to drink the water. In the study area, in terms of water quality, the water resources were in S1 suitability class. However, steep slopes and stoniness were two barriers for water accessibility. As demonstrated by the model, 5552.32 ha $(57.99 \%)$ of the study rangelands were in good class, 1523.85 ha $(25.91 \%)$ in fair to moderate class while 5.76 ha $(0.06 \%)$ were in poor suitability class. Non suitable rangelands were 2369.15 hectares which is equal to $20.4 \%$ of the surface area.
\end{abstract}

Keywords: water resources suitability, rangeland, water resources, distance, livestock

\section{Introduction}

Livestock provide diverse services for humans, and is significantly involved in the livelihoods of people. On the constrary, water is one of the components of livestock feed, therefore safe and sufficient water resources are necessary for most of the physiological functions of livestock as well as optimal production of livestock products. Therefore, if there is sufficient forage and water, the maximum yield of livestock production could be achieved (Mesdaghi, 1998). The amount of forage grazed by livestock depends on the amount of water available in the rangeland; in other words, only if there is sufficient water, can livestock have a maximum use of forage for livestock production (Schoeller, 1997). Water scarcity reduces livestock yield faster than the deficiencies of other nutrients (Lardy et al., 2008). Dunbar and Miller (1993) stated that if livestock don't have access to adequate and safe water daily, food consumption will be reduced, resulting in reduced livestock products and reduced economic benefit. The spatial distribution of grazing in rangelands is also one of the main preconditions for proper livestock grazing. The main objective of livestock distribution is to make the maximum safe use of rangelands without serious threat to other parts (Gillen et al., 1984), and it depends on topography, the quantity and quality 
of available forage, environmental conditions and water resources (Animut and Goessch, 2008).

According to FAO (1993), livestock should not travel a distance of more than $10 \mathrm{~km}$ for water. This is due to the fact that traveling distances, e.g. of more than $10 \mathrm{~km}$, lead to more energy consumption and reduction of grazing times. Holechek (2001) stated that a distance of $1.6 \mathrm{~km}$ is suitable for sheep grazing and demonstrated that a distance of more than $3.2 \mathrm{~km}$ had no usability. The maximum distance that can be traveled by livestock for drinking water under different topographic conditions of flat, gentle, and steep slopes was reported to be 4-6 km, 3-4 km, and 2-2.5 km (Moghadam, 2004). When there are inadequate water resources in rangelands, particularly in terms of number and amount, the concentration of livestock around water resources will be increased thereby leading to soil and vegetation degradation around water resources (Ludwig et al., 2004). Given that the study area has an economically significant role in providing livelihood in the region, the present study was carried out to determine the adequacy of water resources and how they could be accessed. Results could help local people to find way for easier access to fresh water resources which are already existing.

\section{Materials and Methods}

\section{Study area}

The studied watershed in Savadkooh, Mazandaran province of Iran is 21717 hectares, of which 9573 ha, $44.08 \%$ of total area, are rangelands located in the highlands of Mazandaran province between an altitude of $880 \mathrm{~m}$ (at the basin outlet) and $3690 \mathrm{~m}$ (Ghadamgah Mountain). The average annual rainfall is $429 \mathrm{~mm}$ with a Mediterranean climate based on De-marton climate classification ( $\mathrm{Ia}=20.4)$. Generally, Festuca ovina, Bromus tomentellus, Dactylis glomerata, Poa trivialis, Agropyron pectinoforme and Melica persica are dominant vegetation species in the study area, which are grazed by sheep. There is a main stream in this watershed with a length of $9987 \mathrm{~m}$, stretching from northeast to southwest of the watershed. A number of sub-streams are connected to it from different directions, discharging the run off. This river has relatively high discharge rate all year round; therefore, the area residents were never faced with water shortage. Moreover, the study watershed has many springs whose water is consumed by livestock in summer and the surplus is poured into the main stream.

\section{Methodology}

This research was conducted based on FAO (1991) method.To determine the water suitability model, three factors such as water quality, water quantity, and distance from water resources were taken into consideration. Scoring method is described in Tables 1 and 2. On the basis of the results, three maps layers were prepared. Maps were overlayed to create the water suitability map. With the help of FAO (1991) scoring method, range water suitability classes were determined. In this method, the factor receiving the lowest score in the evaluation is determined as the final suitability factor. The advantage of this method is that the range suitability is never over estimated, therefore, there is no threat of over grazing on the rangeland. In the early stages, basic information such as topographic map, information on water resources, livestock, climate, vegetation characteristics, range capacity and other types of data were 
collected. The mapping was done by ARC GIS 10.1 software. To obtain a slope map, Digital Elevation Model (DEM) was built.

\section{The distance sub-model}

In order to determine the availability and access to water resources in the study area, location of water resources were recorded and are indicated on a point map. Thereafter, the equidistant points map on which the range of distances from water resources for any pixel could be seen was prepared. The rangelands were segmented into different properties called Samane Orfi (SO), each belonging to a household. The map of equidistant points for all SOs were incorporated into one final distance map. According to (Table 1), the slope map was classified into four classes and each slope class was represented in a separate map. The map of equidistant points from water resources was also classified for sheep based on data in (Table 1), such that a classification map of equidistant points from water resources is generated for each slope class. Each slope map was overlapped with its corresponding map of equidistant points from water resources to achieve four suitability maps in terms of distance from water resources and slope. The four suitability maps were eventually overlayed and the final map of range suitability classes, in terms of distance from water resources, was made (Table 1).

Table 1. Modifie distance from water resources for sheep in the slope classes of (0-60)\%.

\begin{tabular}{c|cccc}
\hline Slope classes & $0-10 \%$ & $10-30 \%$ & $30-60 \%$ & $>60 \%$ \\
Suitability class & & & \\
\hline S1 & $0-3400 \mathrm{~m}$ & $0-3000 \mathrm{~m}$ & $0-1000 \mathrm{~m}$ & $\mathrm{~N}$ \\
S2 & $3400-5000 \mathrm{~m}$ & $3000-4800 \mathrm{~m}$ & $1000-3600 \mathrm{~m}$ & $\mathrm{~N}$ \\
S3 & $5000-6400 \mathrm{~m}$ & $4800-6000 \mathrm{~m}$ & $3600-4100 \mathrm{~m}$ & $\mathrm{~N}$ \\
$\mathrm{~N}$ & $>6400 \mathrm{~m}$ & $>6000 \mathrm{~m}$ & $>4100 \mathrm{~m}$ & $\mathrm{~N}$ \\
\hline
\end{tabular}

\section{Water quantity sub-model}

The livestock water requirements depend on the type of livestock, forage quality, and weather conditions. Therefore, to determine the quantity of water resources, the flow rate of each water resource was measured separately and the animal unit water requirement was set as 5 liters per day based on the regional conditions and feedbacks from herders. The average flow rate of water resources for each SO was summed. Then it was compared with livestock water requirement to determine the balance and rate the suitability (Table 2).

Table 2. The classes of suitability on the basis of the quantity of available water.

\begin{tabular}{c|cccc}
\hline $\begin{array}{c}\text { Percentage of water need } \\
\text { satisfied }\end{array}$ & $80-100(\%)$ & $40-80(\%)$ & $20-40(\%)$ & $0-20(\%)$ \\
\hline Class of suitability & $\mathrm{S}_{1}$ & $\mathrm{~S}_{2}$ & $\mathrm{~S}_{3}$ & $\mathrm{~N}$ \\
\hline
\end{tabular}




\section{Water quality sub-model}

Generally, livestock prefer fresh and clean water to saline water (Mesdaghi, 1998). Measuring the quality of water with respect to the amount of poisoning elements like salts, water hardness, $\mathrm{pH}$, sulfate, nitrate, etc. is essential for proper range management (Bagley et al., 1997). Factors influencing the suitability of drinking water for sheep were driven out of commonly expressed results by researchers (Mahdavi, 1999; Aganaga, 2002; Kekem, 1984; King, 1983; Sileshi et al., 2003) (Table 3).

Table 3. Factors influencing the quality of drinking water for grazing sheep.

\begin{tabular}{cc}
\hline Factor studied & Maximum tolerance of sheep \\
\hline EC ( mmhos / cm) & 16 \\
Mg (mg / liter) & 500 \\
Total dissolved solids (TDS) & 12900 \\
\hline
\end{tabular}

\section{Results}

Water is a key element for biological activities, therefore lack of it can certainly lead to death more quickly than lack of other essential resources such as feed. In rangelands, livestock production is generally limited due to water scarcity. In other words, the performance of livestock production depends on high-quality water supply, in addition to the availability of forage. Adequate rainfall of $429 \mathrm{~mm}$, results in abundant natural springs. However, these resources are not properly distributed in this area. Maps have shown that water resources are not on the same spots as good quality range vegetation. According to results of the sub-models, water supply exceeds water demand, i.e. 8500 and 245192, respectively. Which implies that there is no water deficit in the area from quantity point of view. Our results clearly indicate that, in terms of water quality, the water resources were in S1 suitability class. Results of accessibilty model demonstrate that $57.99 \%$ of the study area is in S1, 15.91 in S2 and $0.06 \%$ in (S3) classes while $24.04 \%$ of the area is not suitable $(\mathrm{N})$ for grazing as a result of access to water resources. Given that the distance and distribution of water resources in the study area were fairly good, slope was the only limiting factor (Fig. 1). Fig. 2 shows range suitability classes based on water resources for livestock grazing. Water resources suitability classes for livestock grazing are presented in Table 4.

Table 4. Water resources suitability classes for livestock grazing.

\begin{tabular}{c|cc}
\hline Suitability designation & Area (ha) & Area (\%) \\
\hline $\mathrm{S}_{1}$ & 5552.32 & $57.99(\%)$ \\
$\mathrm{S}_{2}$ & 1523.85 & $15.9(\%)$ \\
$\mathrm{S}_{3}$ & 5.76 & $0.06(\%)$ \\
$\mathrm{N}$ & 2369.15 & $24.04(\%)$ \\
total & 9451.08 & $100(\%)$ \\
\hline
\end{tabular}




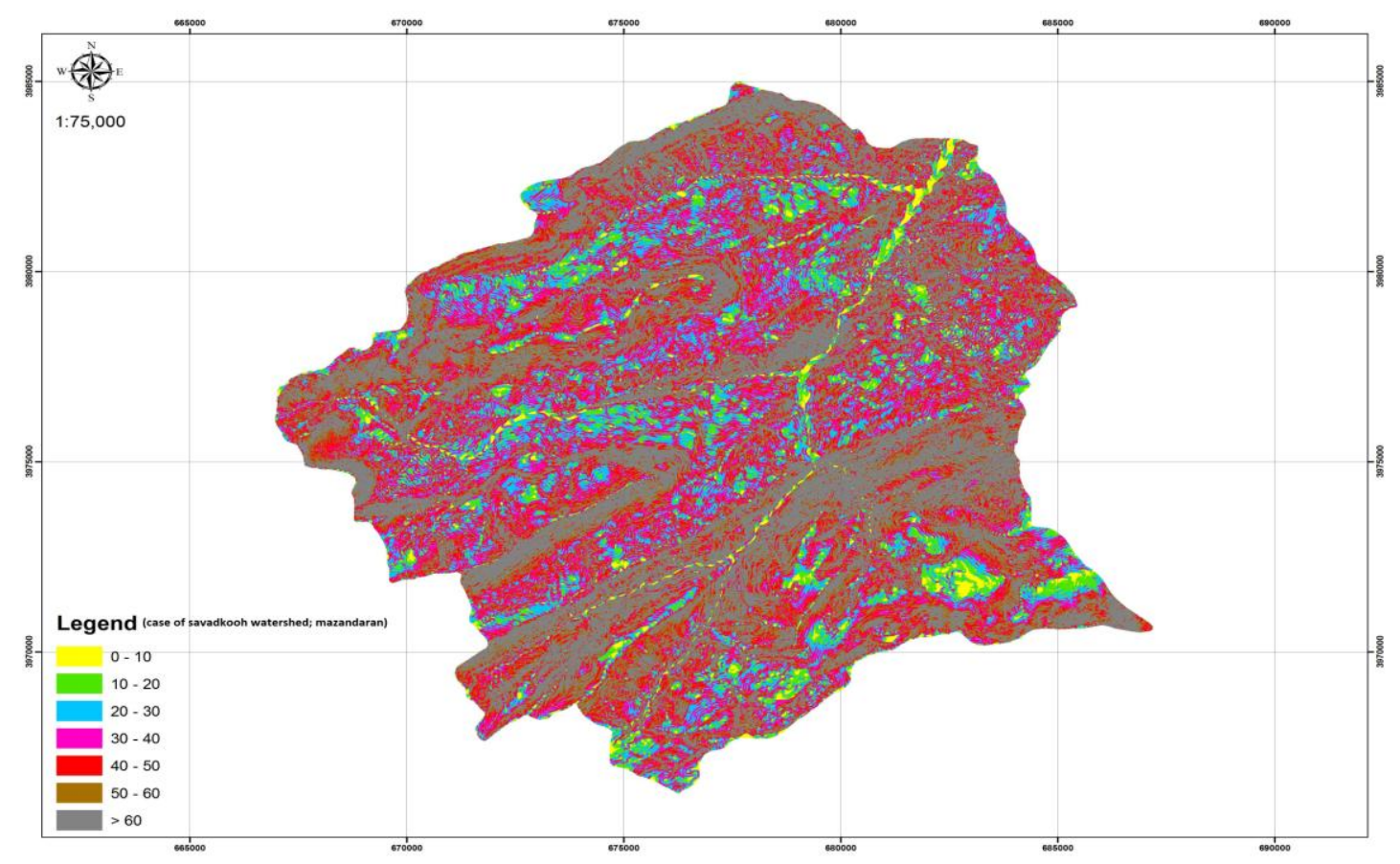

Figure 1. Slope classes of the study area for sheep grazing.

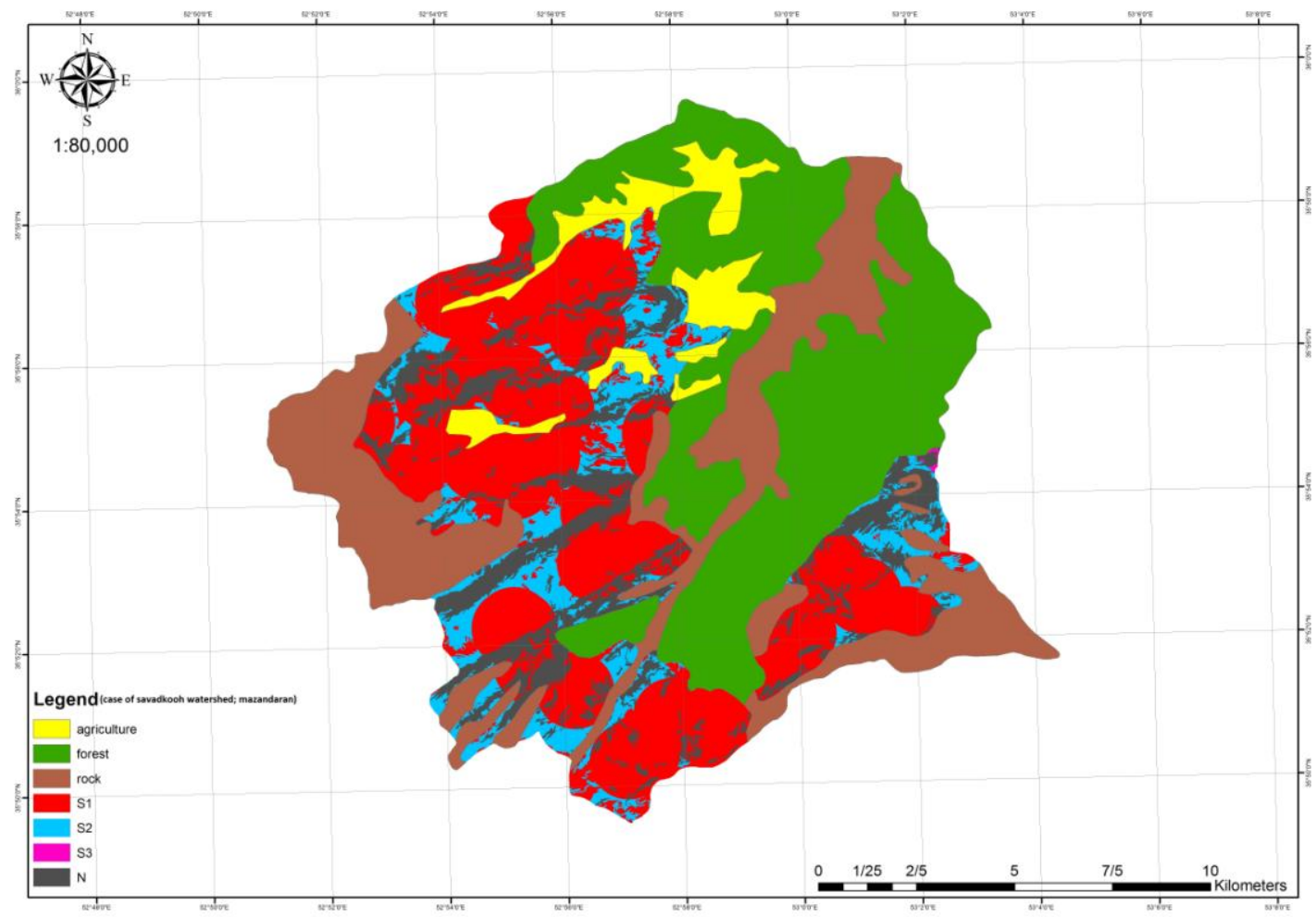

Figure 2. Water resources suitability of the study area for sheep grazing. 


\section{Discussion}

Access to water resources is one of the most important factors, influencing the uniform distribution of livestock. Both slope and distance from water resources are the most influential factors affecting access to water resources. Considering the climatic conditions and number of water resources in the study area, there is no limitation in terms of the quantity and quality of water resources. In the study area, the distance from water resources had no limitations to range suitability for sheep grazing, but the high slope of livestock route to water resources caused a non-suitable class for livestock grazing. Given that the study area is mountainous, slope was determined as a limiting factor (Fig. 1). Our results are in line with the findings reported by Soleimani et al. (2006), Amiri (2009, 2010), Gavili et al. (2010) and Sour et al. (2013). Kiet (2000) carried out a study on rangelands in Australia where slope and access to water resources were reported as the limiting factors for cattle grazing. Actually, the negative impact of slope caused a reduction in livestock distribution and access to water resources (Vallentine, 2001) as well as reduced grazing capacity (Holechek et al., 2001), such that livestock willing to graze were reduced by increasing slope (Gillen et al., 1984). Vallentine (2001) stated that livestock ability to graze was reduced by increasing slope together with spending a lot of energy. Sheep grazing on slopes of less than $45 \%$ is uniform while it is reduced on slopes between 50-70\% (McDaniel and Tiedeman, 1981). Water resources in slopes more than 50\% (Kekem, 1984), and (75\%) were reported to be unsuitable for livestock grazing and wildlife grazing was recommended instead (Zhou, 1989). With increasing slope, soil penetration is reduced and runoff is increased. On the other hand, the establishment of plant species is reduced on steep slopes. Grazing on steep slopes causes soil movement and makes the establishment of plant species more difficult. Additionally, livestock spend a lot of energy to walk on steep slopes (for grazing and to reach the water resources), therefore, the livestock performance is reduced (Holechek et al., 2001).

Squires (2010) stated that access to water resources and its distribution caused a reduced livestock grazing pressure and optimum use of rangeland as well as increased livestock performance. According to Holechek et al. (2001), slopes more than $60 \%$ are not suitable for livestock grazing, and in the present study, $27.74 \%$ of the rangelands studied are classified in this slope class. Nevertheless, rangelands with a slope of over $60 \%$ are not only suitable for sheep grazing due to the limited access of livestock to water resources but also unsuitable for livestock grazing in terms of preventing erosion and soil conservation as well as preventing the degradation of rangelands (Arzani et al., 2005, Arzani et al., 2006). Therefore, other land uses such as wild life grazing, ecotourism, and medicinal and industrial species are recommended for these rangelands. Consequently, livestock grazing on high slopes is not recommended in terms of sustainable use of rangelands.

\section{Conclusion}

Generally, slope is an important factor for limiting range suitability. Therefore, in such area, water resources need to be distributed taking topography condition into consideration. 


\section{REFERENCES}

[1] Aganga, A. (2002): Water utilization by sheep and goats in northen Nigeria. - FAO corporate document Repository, http://www.FAO.Org/DOCREP.

[2] Amiri, F. (2009): A GIS model for determination of water resources suitability for goats grazing. - African Journal of Agricultural Research 4 (1): 014-020, Available online at http://www.academicjournals.Org/AJAR, ISSN 1991-637X@ 2009 Academic Journals.

[3] Amiri, F. (2010): Modeling Livestock Grazing in Rangeland By GIS. - World Engineerin Congress 2010, 2nd-5th August Kuching Sarawak Malaysia Conference on Geomatics and Geographical Information Science 77-90. pp.

[4] Animut, G., Goessch, A.L. (2008): Co-grazing of sheep and goats: Benefits and constraints. - Small Ruminant Research 77: 127 - 145.

[5] Arzani, H., Jangjoo, M., Shams, H., Mohtashamnia, S., Fashami, M.A., Ahmadi, H., Jafari, M., Darvishsefat, A., Shahriary, E. (2006): A Model for Classification of Range Suitability for Sheep grazing in Central Alborz, Ardestan and Zagros Region. - Journal Sci \& Technol. Agri \& Nature Resourse, University of Isfahan. Technol, Iran 10 (1): 273289.

[6] Arzani, H., Yousefi, SH., Jafari, M., Farahpour, M. (2005): A Model of Determination of Range Suitability for Sheep Grazing whit Using GIS Technique in Taleghan Region. Journal of Environment, University of Tehran.

[7] Bagley, C.V., Amacher, J.K., Kitt, F.P. (1997): Analysis of water quality for livestok. Utah State Extension. - Animal Health Fact sheet, Utah State University. Logan, Utah. (EP/DF/07-97), p.7.

[8] Bruynooghe, J., Macdonald, R. (2008): Managing Saskatchewan Rangeland, Agriculture and Agri - Food Canada's Greencover Canada Program 106 pp.

[9] Dunbar, J.R., Miller, R.O. (1993): Assessing Water Quality for Livestock Under Drought Conditions. - Drought tip 92-30, California Department of Water Resources - Water Conservation Office

[10] F.A.O. (1991): Guidelines land evaluation for extensive grazing, Soil Resource Management and Conservation Service. Soil Bull, No. 58, Rome.

[11] F.A.O. (1993): Guideline for land use planning. FAO development series. NO. 1, FAO, Rome (Italy) 96. pp.

[12] Gavili, E., Ghasriani, F., Arzani, H., Vahabi, M., Amiri, F. (2011): Determine water resources accessibility for sheep grazing by GIS technology (Case study: Feraidun Shahr rangeland in Isfahan Province). - Journal of Applied RS and GIS Technology in Natural Resource Science 1(1): 89-99. (In Persian).

[13] Gillen, R.L., Krueger, W.C., Miller, R.F. (1984): Cattle distribution on mountain rangeland in northeastern Oregon. - Journal of Range Management (37): 549-553.

[14] Holechek, J.L., Pieper, D., Herbal, C.H. (2001): Range Management Principles and Practices. - 4th (ed). Prentice Hall Upper Saddle River NJ.

[15] Kekem, A.S. (1984): Land Evaluation study in Mount Kula Marsh bit area Northern Kenya. - In: Siderius proceedings of the work shop on land evaluation for Extensive Grazing ILIDRT wagenings, 257- 274.

[16] Kiet, S. (2000): Expected use GIS map. - Rangeland 22 (2): 18-20.

[17] King, J.M. (1983): Livestock water needs in pastoral Africa in relation to climate and forage. - Research Report No. 7. International Livestock Center for Africa (Nairobi, Kenya), cited Wilson 1989.

[18] Lardy, G., Stoltenow, C.H., Johnson, R. (2008): Livestock and water. - AS - 954. North Dakota State University, Fargo, North Dakota 5858105.http: //www.ag.ndsu.nodak.edu.

[19] Ludwig, J.A., Tongway, D.J., Bastin G.N., James, C.D. (2004): Monitoring ecological indicators of rangeland functional integrity and their relation to biodiversity at local to regional scales. - Journal of Australian Ecological (29): 108-120. 
[20] Mahdavi, M. (1999): Applied Hydrology. - second volume, second edition, Tehran University Publications, 401 pages.

[21] McDaniel, K.C., Tiedeman, J.A. (1981): Sheep use on mountain winter range in New Mexico. - Journal of range management 34 (2): 102-104.

[22] Mesdaghi, M. (1998): Range management in Iran. - Jahad Daneshgahi Mashhad pub. 259 pp. (in Persian).

[23] Moghadam, M.R. (2004): Rangeland and range management. - University of Tehran pub. 470 pp. (in Persian).

[24] Schoeller, H.J. (1977): Geochemistry of groundwater. In: Groundwater Studies. - An International Guide for Research and Practice. UNESCO, Paris. 18pp.

[25] Sileshi, Z., Tegegne, A., Tsadik, G. (2003): Water resources for livestock in Ethiopia: Implications for research and development, MoWR/EARO/IWMI/ILRI Workshop. ILRI, Addis Ababa, Ethiopia. ISBN: 92-9146 -140-7. P. 66-79.

[26] Soleimani, K., Khormali, S., Habib Nejad, M. (2006): GIS and RS Based classification of Erosion in Lasem watershed. - Iran international conference of map Asia. 29 August September. Bankok.

[27] Sour, A., Arzani, H., Farahpour, M., Alizadeh, E., Amiri, F. ( 2013): Assessment of water resources propriety for common use of cow and sheep by GIS (Case study: Piranshahr province rangelands). - Journal of Applied RS \& GIS Techniques in Natural Resource Science 3(4): 15-27. (In Persian).

[28] Squires, V.R., Wicson, A.D. (1971): Distance between Food and water supply and it's effect on drinking Frequency and water in take of merino sheep and Border Leicester sheep. - Australian Journal of Agricultural Research (22): 283-290.

[29] Sys, I. (1983): Evalution of the physical environment for agriculture use in the humid topic. - Koniklyke Academic, Brussel.

[30] Vallentine, J.F. (2001): Grazing management. - Academic Press. San Diego, CA.

[31] Zhou, Q. (1989): Land resources management using remote sensing and geographical information system in the Australian Arid Zone. - Ph.D Thesis, the University of New Sout Wales, Australia. 